\title{
Microscopic Characteristics of Leaf Epidermal Cells and Flowers in Two Types of Ficus Tikoua Bur.
}

\author{
Di-ya LEI ${ }^{1, \#}$, Hao-ru TANG ${ }^{1, \#}$, Yan WANG ${ }^{2}$ and Qing CHEN ${ }^{1, a, *}$ \\ ${ }^{1}$ College of Horticulture, Sichuan Agricultural University, Chengdu 611130, Sichuan, \\ China \\ ${ }^{2}$ Institute of Pomology and Olericulture, Sichuan Agricultural University, Chengdu \\ 611130, Sichuan, China \\ \#These authors contributed equally to this work \\ asupnovel@gmail.com \\ ${ }^{*}$ Corresponding author
}

Keywords: Ficus, Leaf epidermis morphology, Microscopic observation of male and female flowers.

\begin{abstract}
Ficus tikoua is one of a special species in genus Ficus, Moraceae, which characterized by its creeping vine structures. Generally, there are two different types of plants in the species: the commonly mistakenly known 'Male Ficus' which is edible, and the other hypothetical 'Female Ficus', which are not edible. It is difficult to distinguish them through the outer appearance like through stems characters or leaves shapes. Botanically, these two are corresponding to the 'normal inflorescence' syconia and 'gall flowers inflorescence' syconia. Currently, most studies confined to the former one, while the characteristics of the latter, as well as the differences between the two has not yet been reported. In this experiment, leaf epidermis microscopic characteristics (number of stoma, pore size, existence of cystoliths) were observed and compared between the two. The results showed that: 'male and female inflorescence' has larger stoma (average size of $39.55 \mu \mathrm{m}$ long and $29.13 \mu \mathrm{m}$ wide) but has a smaller density $\left(2420 / \mathrm{mm}^{2}\right)$; In addition, two strains both have obvious linear stalactitic structure with $17.10 \mu \mathrm{m}$ in width. The cell size has little difference between the two. Obvious anatomical differences were observed in the fruit: 'male and female inflorescence' has a clear structure for stamens and pistils, but the quantities of pistils with lateral stigma and fused bracts are much higher than stamens. The 'gall Flower' plants have no obvious typical inflorescence structure, a uniform rod protruding epidermis, and occasionally lateral style, a slender, but with not obvious ovary. These results could provide basic information for the understanding of these wild fruit resources.
\end{abstract}

\section{Introduction}

Ficus tikoua Bur, are plants of Ficus, Moraceae. Two different types of this species are recognized, the commonly mistaken 'Male Ficus' and the hypothetic 'Female Ficus'. The plants are distributed in Henan, Hubei, Guangxi, Sichuan, Yunnan, Tibet and Guizhou provinces in China, and have been grown in India [1]. The stems are brown with knots enlarged. It has long and slender adventitious roots. The new stem node is reddish brown while the old stem node is dark brown. Leave veins at basal side are shorter, with 3-4 pairs lateral veins, and covered by short hair. The abaxial leaf veins have fine hair. Epidermal leaf skins are covered with tumor-like spots [2]. Fruits grow paired or clustered on the stolon knot in the soil, spherical to oval in shape, one to two 
centimeters in diameter. The fruits get dark red when mature. Multi-circular tumor point structures can be found on the fruit surface. Botanically, the fruits are actually specialized structures called syconia bearing minute male and female flowers on the inside [3]. The first type is characterized by short-style female flowers, ovary of which tiny female wasps can deposit their eggs in. Flowers of this type cannot develop into regular seeds for the injures in the ovary. The other type of fruit has female flowers with long-style, which are not suitable for the injection of wasps' ovipositor. The latter flowers each can develop a seed (with an embryo and endosperm) by normal pollination and double fertilization [3]. It is difficult to distinguish through the outer appearance like through stems characters or leave shapes. Here in this study, we provide microscopic characteristics of leaf epidermal cells and flowers to distinguish these two types.

\section{Materials and Methods}

\section{Leaf Observation}

Microscopic characteristics of leaves were observed referring to Boso et al. ${ }^{[4]}$. Briefly, mature leaves of the two types of Ficus tikoua were collected in the field of Pengxi county, sichuan province. The leaves were cut into small squares about $0.5 \mathrm{~cm}^{2}$. Leaf disks along the middle vein were instantly immersed in $4 \%$ glutaraldehyde solution. 0.2 $\mathrm{mol} / \mathrm{L}$ phosphate buffer was used to clean the material five times. Leaves were soften by boiling in $\mathrm{ddH}_{2} \mathrm{O}$ for $10 \mathrm{~min}$, then soaked in $30 \%$ sodium hypochlorite solution. After an incubation at $35^{\circ} \mathrm{C}$ for about 4 to $5 \mathrm{~h}$, the leaf disks get white. They were cleaned with distilled water. The samples were stripped with $1 \%$ red dye solution, dehydrated in turn in $30 \%, 50 \%, 60 \%$, and $70 \%$ ethanol successively. The mounted slides were covered with $1 \%$ glycerol before microscope observation. Leaf epidermal cell shape, stoma size and density were compared. On the adaxial epidermis, 30 stomata were randomly selected to measure the length and width. The density of stomata is measured: $D=N / S$, where $\mathrm{D}$ is the density of the stoma, $\mathrm{N}$ is the number of pores in the single field of view, and $\mathrm{S}$ is the area of single field of view $\left(\mathrm{mm}^{2}\right)$. The stomatal index were calculated $\mathrm{SI}=$ $\mathrm{S} /(\mathrm{E}+\mathrm{S}) \times 100$, where $\mathrm{S}$ represents the number of stomata in the unit area, and $\mathrm{E}$ represents the number of cells in the same area.

\section{Anatomical Observation of Ficus Tikoua Fruit}

The fruits were dissected at the phase when syconium ostiole open, female flowers can be pollinated. This phase can last three to six days and can be extended without pollination. The pistil and stamen of the syconia were observed and photographed with a binocular stereo microscope with a camera.

\section{Results}

The epidermis of the mature leaves of the two types of Ficus tikoua plants was examined. The 'normal inflorescence' tikoua plants have a smaller stoma density of 2420 per $\mathrm{mm}^{2}$ on average (Fig. 1B) when compared with 'gall flower', which has 2961 stomata per $\mathrm{mm}^{2}$ (Fig. 1A). For the size of the stoma, the "gall flower inflorescence" is slightly longer $(4.84 \mu \mathrm{m}$, Fig. 1E) than the 'normal' type plants $(3.96 \mu \mathrm{m}$, Fig. 1D). However, the latter has larger guard cells (Fig. 1D). Moreover, two strains both have obvious linear arranged stalactitic structures (Fig. 1C and 1F) on the leaf surface. 

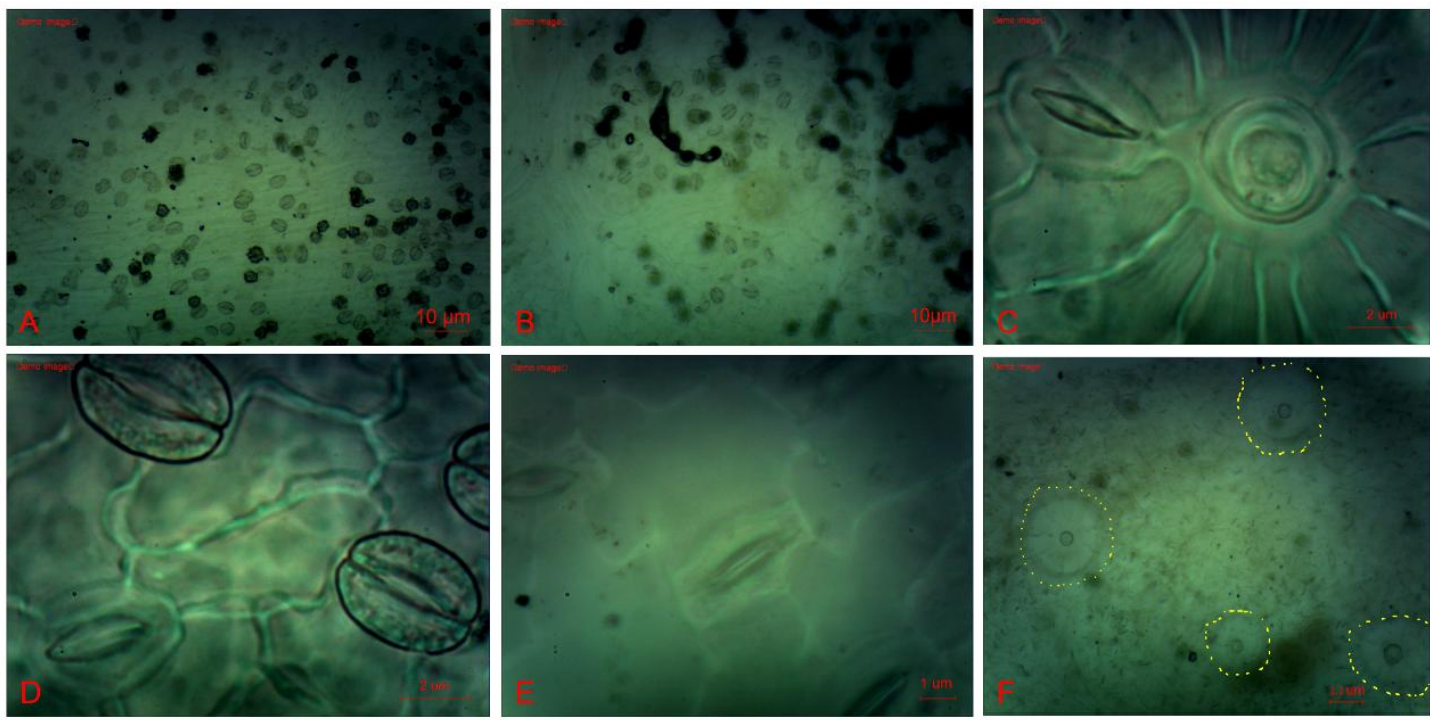

Figure 1. Microscopic leaf characteristics of both types of Ficus tikoua. A, C, D and F were from 'normal' type, and B and E were from 'gall flower' type plants.

In the syconia, densities of pistil in the normal type fruit is slightly higher ( 0.96 per $\left.\mathrm{mm}^{2}\right)$ than that in gall flower type fruit $\left(0.64\right.$ per $\left.\mathrm{mm}^{2}\right)$ (Fig. 2A and 2B). The stigma length in the normal type is $41.33 \mu \mathrm{m}$ on average, which is significantly longer than those of gall flower type $(30.26 \mu \mathrm{m}, \mathrm{p}=0.000)$. The normal type flower can be fertilized normally and develope into a regular seed containing fruit (Fig. 2C). However, few flower in the gall type can be normally fertilized. The pistils were dried (Fig. 2B), and the ovaries are getting shrink (Fig. 2D). This apoptosis was due to oviposit injection of female wasps and egg hatches in the ovary.
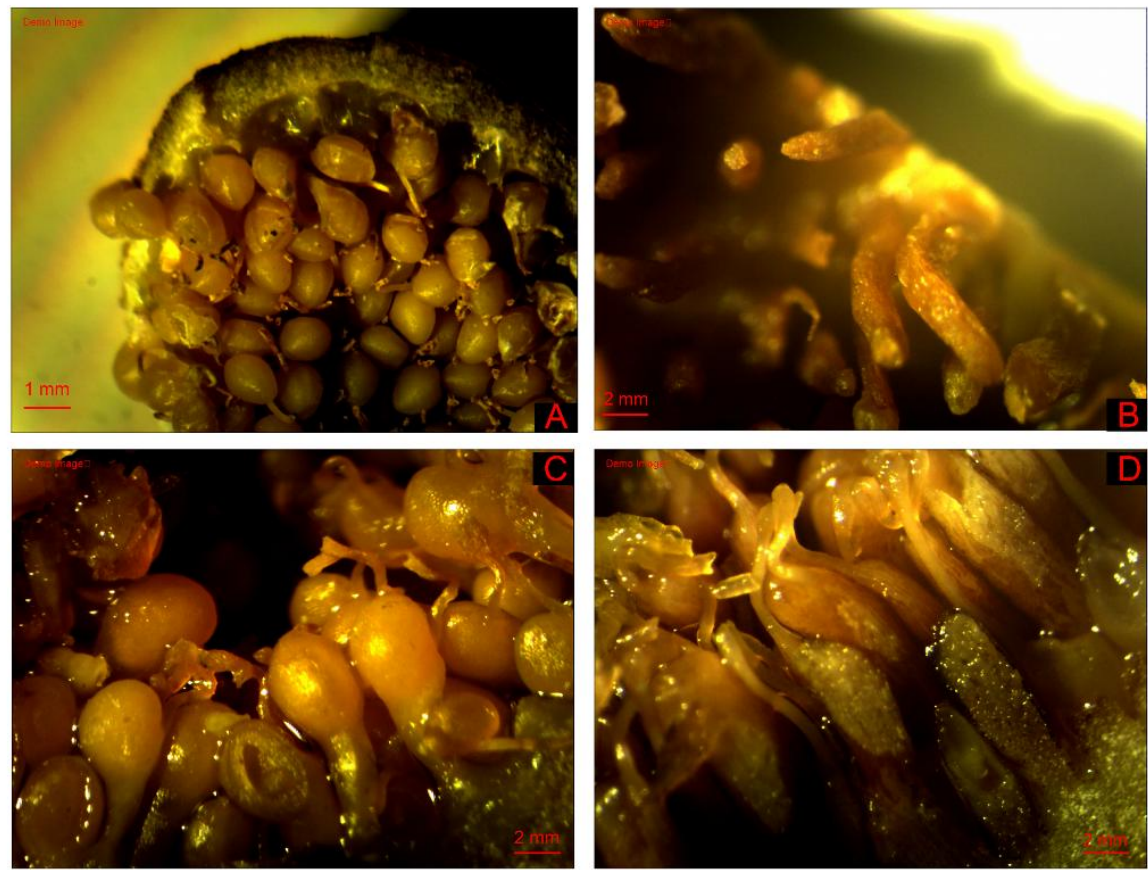

Figure 2. Microscopic flower characteristics of both types of Ficus tikoua. A, C were from 'normal' type, and B and D were from 'gall flower' type plants. 


\section{Discussion}

In nature, gall flower type Ficus tikoua usually grow in conditions with more shade and higher moisture. The higher density of stomata could be benefit for respiration and photosynthesis process. In contrary, the edible type of Ficus tikoua usually grows in fields with relatively higher illumination intensity. The observed lower level of stoma density could attribute to adaption of water evaporation. Through the observations of the pistil and ovaries in the fruit, the obvious differences between the two types of tikoua were the pistil length. Although some of the sycomorus contain female flowers that also can be pollinated and give birth of seeds, most of the gall-flower fruits cannot and will only leave dried hollowed crowed ovaries [3]. The mistaken female and male plants concepts should have a clear explanation. Since the first description of these phenomena, we provide additional evidences.

\section{References}

[1] L.B. Chaudhary, J.V. Sudhakar, A. Kumar A, Synopsis of genus Ficus L. (Moraceae) in India. Taiwania, 2012, 57(2):193-216.

[2] Z.Y. Wu, P.H. Raven, D.Y. Hong, Flora of China, Ulmaceae through Basellaceae, 2003, 5 .

[3] I.J. Condit, S.E. Flanders, Gall-flower of the Fig, a misnomer. Science, 1945, 102(2640), 128-130.

[4] S. Boso, V. Alonso-Villaverde, J.L. Santiago, P. Gago Montana, M. Durrenberger, M. Duggelin, H.H. Kassemeyer, R. Martinez, C. Maria, Macro- and microscopic leaf characteristics of six grapevine genotypes (Vitis spp.) with different susceptibilities to grapevine downy mildew. Vitis 2010, 49(1), 43-50. 